\title{
Weed Management in Kharif Groundnut
}

\author{
V.D. Vora*, A.D. Parmar, D.S. Hirpara, K.K. Kanzaria, N.R. Desai, \\ S.C. Kaneria and V.L. Modhavadiya \\ Dry Farming Research Station, Junagadh Agricultural University, \\ Targhadia (Gujarat)-360 003, India \\ *Corresponding author
}

\section{Keywords}

Groundnut, Weed control, Weed control efficiency, Weed index

Article Info

Accepted:

07 October 2019

Available Online:

10 November 2019

\section{A B S T R A C T}

A field experiment was conducted on medium black soil to study the effect of different treatments of weed control on groundnut (Arachis hypogaea) yield at Dry Farming Research Station, Junagadh Agricultural University, Jamkhambhalia, Gujarat during kharif-2013 to 2018. The experiment comprising of 12 treatments with three replications laid out in randomized block design. The pooled results revealed that weed free ( $\mathrm{HW}$ and IC at $15,30,45$ and 60 DAS) treatment recorded significantly higher pod yield (2115 $\mathrm{kg} / \mathrm{ha}$ ), haulm yield (4919 kg/ha), maximum weed control efficiency $(74.21 \%)$ and lowest dry weight of weed (492 kg/ha) with maximum net return $(78857$ Rs/ha)and BCR (2.93). However, integrated weed management practicesi.e.post emergence application of Quizalofop-ethyl @ $40 \mathrm{~g} / \mathrm{ha}$ at 20 days after sowing followed by one hand weeding and one interculturing and pre- emergence application of Oxyfluorfen @ $0.24 \mathrm{~kg} / \mathrm{ha}$ followed by one hand weeding and one interculturing at 40 days after sowing also recorded higher weed control efficiency, yield attributes, pod yield and haulm yield compared to other treatments.

\section{Introduction}

Groundnut (Arachis hypogea L.) is one of the most important oilseed crop, cultivated for edible oil, protein and confectionery purpose. Kharif groundnut cultivation required frequent weed control practices for higher seed production, because groundnut is highly susceptible to weed infestation due to its slow growth rate at initial stage and its physiological characteristics like short plant height and underground pod bearing habit. Uncontrolled weed reduces the yield of Kharif groundnut by 54 to $71 \%$ especially during early period of crop growth (Agasimani et al., 2010). Unlike the other crops in groundnut weed surges difficulties in pegging, growing, pod developing and harvesting and also 
competing with crops for essential resources like nutrients, sunlight, water, air etc. The critical period of weed competition was found to be 4 to 8 weeks after sowing (Hamada, 1988).

Therefore, weeding should be completed before the pegging stage in groundnut. In present situation manual weeding is costlier and increase the production cost.

To avoid such experience one should require the most effective weedicide under rain fed condition. Pre-emergence (PE) herbicides viz. pendimethalin (Patel et al., 2013) and oxyfluorfen (Ramalingam et al., 2013) and post-emergence (POE) herbicides, viz. imazethapyr (Kalhapure 2013) and quizal of op-ethyl (Samant et al., 2014) were found very effective in controlling weeds, higher crop yield and increased income in different parts of the country. Thus, this experiment was planned to know the feasibility of weedicides in groundnut under rainfed condition.

\section{Materials and Methods}

The experiment was conducted on medium black soil of dry farming research station, of Junagadh Agricultural University, Jamkhambhalia (Gujarat) during six consecutive kharif seasons of 2013-14 to 2018-19. The year wise total rainfall received during the crop growth seasons2013 to 2018 were 1263.6, 324.7, 241, 688, 731 and 523 $\mathrm{mm}$, with $33,19,12,17,21$ and 10 rainy days, respectively.

The soil of the experimental field was medium black having good drainage and high moisture retentive capacity. Some important characteristics of the soil were $\mathrm{p}^{\mathrm{H}} 8.30$, EC $0.35 \mathrm{dS} / \mathrm{m}$, Organic carbon $0.41 \%$, available $\mathrm{N}, \mathrm{P}, \mathrm{K}$ and $\mathrm{S}$ were $230.3,28.6$, and $336 \mathrm{~kg} / \mathrm{ha}$ and $17.8 \mathrm{ppm}$, respectivelyand micronutrient
$\mathrm{Fe}, \mathrm{Mn}$ and $\mathrm{Zn}$ were 10.19, 12.84and o.66ppm, respectively. Total twelve treatments, comprising seven treatments of pre-emergence or post emergence herbicides (pendimethalin $30 \%$ and $37.5 \%$, oxyflourfen, Quizalofop ethyl, Imazethapyr Oxadiargyl, Propaquizafop) combined with one hand weeding and one interculturing at 40 days after sowing, one treatment comprising only cultural practices like hand weeding and interculturing at 20 and 40 days after sowing, two treatments comprising both pre and post emergence herbicides, one treatment as weed free (HW and IC at 15,30,45 and 60 DAS) and one treatment as weedy check.

The experiment was laid out in randomized block design with three replications and individual plot size of $5.0 \mathrm{~m} \mathrm{X} 3.6 \mathrm{~m}$ (gross) and $4.0 \mathrm{mX} 2.4 \mathrm{~m}$ (net). Groundnut seeds of cv. $G G-20$ were sown at $60 \mathrm{~cm}$ row to row and $15 \mathrm{~cm}$ plant to plant distance with bullock drawn seed drill. The crop was fertilized with 12.5- 25-00 NPK kg/ha. Pre emergence application of herbicides was applied as per the treatment immediately after the sowing. All other recommended agricultural practices were done throughout the crop seasons. Yield and yield attributes, dry weight of weeds per net plot were recorded at the time of crop harvest.

Economics of all the treatments was worked out. The weed control efficiency (WCE) and weed index (WI) was calculated by using following formula.

$$
\begin{aligned}
& \text { WCE (\%) } \\
& \text { Weed dry weight }(\mathrm{kg}) \text { in - Weed dry weight }(\mathrm{kg}) \\
& \text { Unweeded plot in treated plot X } 100 \\
& \text { Weed dry weight }(\mathrm{kg}) \text { in unweeded plot } \\
& \text { WI (\%) } \\
& \text { Yield from weed - Yield from treated } \\
& \begin{array}{lll}
\text { free plot } & \text { plot } & \text { X } 100
\end{array} \\
& \text { Yield from weed free plot }
\end{aligned}
$$




\section{Results and Discussion}

\section{Effect on dry weight of weed, WCE, WI and Yield attribute}

The results indicated (Table 1) that the significantly the highest dry weight of weed $(1910 \mathrm{~kg} / \mathrm{ha})$ was observed under the weedy check as compared to all other treatments.

The significantly lower dry weight of weed was recorded under weed free treatment (HW and IC at 15,30,45 and 60 DAS), which was at par with treatments Pendimethalin 30\% EC @ $0.90 \mathrm{~kg} / \mathrm{ha} \mathrm{PE}+1 \mathrm{HW}$ and $1 \mathrm{IC}$ at $40 \mathrm{DAS}$, Pendimethalin 38.7\% CS @ 0.75 kg/ha PPI + $1 \mathrm{HW}$ and $1 \mathrm{IC}$ at 40 DAS and Oxyfluorfen@ $0.24 \mathrm{~kg} / \mathrm{ha} \mathrm{PE}+1 \mathrm{HW}$ and $1 \mathrm{IC}$ at 40 DAS.

The highest weed control efficiency $(74.2 \%)$ and the lowest weed index $(0.0 \%)$ were recorded under weed free treatment (HW and IC at 15,30,45 and 60 DAS). Similarly, preemergence application of Pendimethalin $38.7 \%$ CS @ $0.75 \mathrm{~kg} / \mathrm{ha}$ PPI + $1 \mathrm{HW}$ and 1 IC at 40 DAS, Pendimethalin 30\% EC @ 0.90 $\mathrm{kg} / \mathrm{ha} \mathrm{PE}+1 \mathrm{HW}$ and $1 \mathrm{IC}$ at 40 DAS and Oxyfluorfen@0.24 kg/ha PE + $1 \mathrm{HW}$ and 1 IC at 40 DAS recorded remarkably higher weed control efficiency 73.5, 72.6 and $72.1 \%$, followed by weed free treatment, respectively.

The post-emergence application of herbicides coupled with 1 hand weeding and interculturing at 40 DAS sowing recorded lower weed control efficiency as compared to pre-emergence application of weedicide coupled with 1 hand weeding and interculturing at 40 DAS. It is also noted that the only pre-emergence application of herbicide coupled with post-emergence herbicide at 30 DAS also recorded lower weed control efficiency as compared to weed free and pre-emergence application of herbicide coupled with $1 \mathrm{HW}$ and $1 \mathrm{IC}$ at 40 DAS
(Dutta et al., 2005, Solanki et al., 2005 and Kalhapure et al., 2013).

\section{Effect on yield attributes}

The data in table 1 showed that significantly the highest number of pods (19.5) and shellling \% (75\%) were recorded under weed free treatment, which was followed by postemergence application of Quizalofop-ethyl @ $40 \mathrm{~g} / \mathrm{ha}$ at 20 DAS coupled with one hand weeding and one interculturing at 40 DAS $(17.5 \& \quad 72.7 \%)$ and pre-emergence application of Oxyfluorfen @ 0.24 g/ha coupled with one hand weeding and one interculturing at 40 DAS (16.6 and $72.9 \%$ ). (Dutta et al., 2005 and Bhatt et al., 2010).

\section{Effect on yield}

Among different weed control treatments (Table 2) the significantly the highest pod yield of groundnut was recoded under weed free check $(2115 \mathrm{~kg} / \mathrm{ha})$, which was followed by post-emergence application of Quizalofopethyl @ $40 \mathrm{~g} / \mathrm{ha}$ at 20 DAS coupled with one hand weeding and one interculturing at 40 DAS (1690 kg/ha) and pre-emergence application of Oxyfluorfen @ $0.24 \mathrm{~g} / \mathrm{ha}$ coupled with one hand weeding and one interculturing at 40 DAS (1679 kg/ha). In case of haulm yield the significantly the highest haulm yield of groundnut was recoded under weed free check (4919 kg/ha), which was followed by pre-emergence application of Oxyfluorfen@0.24 g/ha coupled with one hand weeding and one interculturing at 40 DAS $(3950 \mathrm{~kg} / \mathrm{ha})$ and post-emergence application of Quizalofop-ethyl @ $40 \mathrm{~g} / \mathrm{ha}$ at 20 DAS coupled with one hand weeding and one interculturing at 40 DAS (3938 kg/ha). The unweeded control treatment recorded significantly the lowest pod $(865 \mathrm{~kg} / \mathrm{ha})$ and haulm (1878 kg/ha) yield. (Bhatt et al., 2010, Swetha et al., 2016 and Solanki et al., 2005) 
Table.1 Effect of different treatments on dry weight of weed, WCE, WI and yield attributes of groundnut (pooled- six years)

\begin{tabular}{|c|c|c|c|c|c|}
\hline Treatment & $\begin{array}{l}\text { No. of } \\
\text { pods/ } \\
\text { plant }\end{array}$ & $\begin{array}{c}\text { Shellin } \\
\text { g \% }\end{array}$ & $\begin{array}{l}\text { Weed dry } \\
\text { weight } \\
\text { (kg/ha) }\end{array}$ & $\begin{array}{c}\text { WCE } \\
(\%)\end{array}$ & $\begin{array}{l}\text { WI } \\
(\%)\end{array}$ \\
\hline $\begin{array}{l}\text { Pendimethalin 30\% EC @ } 0.90 \mathrm{~kg} / \mathrm{ha} \mathrm{PE} \\
+1 \mathrm{HW} \text { and } 1 \text { IC at } 40 \text { DAS }\end{array}$ & 15.1 & 72.7 & 524.0 & 72.6 & 26.4 \\
\hline $\begin{array}{c}\text { Pendimethalin } 38.7 \% \text { CS @ } 0.75 \mathrm{~kg} / \mathrm{ha} \\
\text { PPI + } 1 \text { HW and } 1 \text { IC at } 40 \text { DAS }\end{array}$ & 15.1 & 72.0 & 506.0 & 73.5 & 28.2 \\
\hline $\begin{array}{c}\text { Oxyfluorfen@0.24 kg/ha PE + } 1 \mathrm{HW} \text { and } \\
1 \text { IC at } 40 \mathrm{DAS}\end{array}$ & 16.6 & 72.9 & 532.0 & 72.1 & 20.6 \\
\hline $\begin{array}{c}\text { Quizalofop-ethyl @ } 40 \text { g/ha POE at } 20 \\
\text { DAS + 1HW and } 1 \text { IC at } 40 \text { DAS }\end{array}$ & 17.5 & 72.7 & 787.0 & 58.8 & 20.1 \\
\hline $\begin{array}{c}\text { Imazethapyr @ } 75 \text { g/ha POE at } 20 \text { DAS + } \\
1 \text { HW and } 1 \text { IC at } 40 \text { DAS }\end{array}$ & 13.6 & 72.3 & 744.0 & 61.1 & 39.1 \\
\hline $\begin{array}{c}\text { Oxadiargyl @ } 90 \text { g/ha POE at } 20 \text { DAS + } 1 \\
\text { HW\& } 1 \text { IC at } 40 \text { DAS }\end{array}$ & 13.7 & 71.6 & 1172.0 & 38.6 & 41.6 \\
\hline $\begin{array}{c}\text { Propaquizafop @ } 90 \text { g/ha POE at } 20 \text { DAS } \\
\quad+1 \text { HW and } 1 \text { IC at } 40 \text { DAS }\end{array}$ & 14.7 & 72.4 & 894.0 & 53.2 & 25.3 \\
\hline HW and IC at 20 and 40 DAS & 14.1 & 71.4 & 1134.0 & 40.6 & 37.7 \\
\hline $\begin{array}{c}\text { Pendimethalin 30\% EC @ } 0.90 \text { kg/ha } \\
\text { PE+Imazethapyr @ } 75 \text { g/ha POE at } 30 \\
\text { DAS }\end{array}$ & 15.1 & 72.5 & 770.0 & 59.7 & 37.3 \\
\hline $\begin{array}{l}\text { Pendimethalin 30\% EC @ } 0.90 \text { kg/ha PE } \\
\text { +Oxadiargyl @ 90 g/ha POE at } 30 \text { DAS }\end{array}$ & 14.6 & 72.6 & 961.0 & 49.7 & 40.4 \\
\hline $\begin{array}{c}\text { Weed free (HW and IC at } 15,30,45 \& 60 \\
\text { DAS) }\end{array}$ & 19.5 & 75.0 & 492.0 & 74.2 & 0.0 \\
\hline Unweeded control & 11.2 & 67.6 & 1910.0 & 0.0 & 26.4 \\
\hline S.Em. \pm & 0.59 & 0 & 86 & & \\
\hline C.D. at 5\% & 1.67 & 1 & 244 & & \\
\hline C.V.\% & 5.62 & 11.7 & 16 & & \\
\hline
\end{tabular}


Table.2 Effect of different treatments on crop yield and economics (pooled-six years)

\begin{tabular}{|c|c|c|c|c|c|c|}
\hline Treatment & $\begin{array}{c}\text { Pod } \\
\text { yield } \\
\text { (kg/ha) }\end{array}$ & $\begin{array}{l}\text { Haulm } \\
\text { yield } \\
\text { (kg/ha) }\end{array}$ & $\begin{array}{l}\text { Gross } \\
\text { Returns } \\
\text { (Rs./ha) }\end{array}$ & $\begin{array}{l}\text { Cost of } \\
\text { cultivation } \\
\text { (Rs./ha) }\end{array}$ & $\begin{array}{l}\text { Net } \\
\text { returns } \\
\text { (Rs./ha) }\end{array}$ & B:C \\
\hline $\begin{array}{l}\text { Pendimethalin 30\% EC @ } 0.90 \mathrm{~kg} / \mathrm{ha} \\
\text { PE + } 1 \text { HW and } 1 \text { IC at } 40 \text { DAS }\end{array}$ & 1557 & 3675 & 88426 & 28755 & 59671 & 3.08 \\
\hline $\begin{array}{c}\text { Pendimethalin } 38.7 \% \text { CS @ } 0.75 \mathrm{~kg} / \mathrm{ha} \\
\text { PPI + } 1 \mathrm{HW} \text { and } 1 \text { IC at } 40 \text { DAS }\end{array}$ & 1520 & 3553 & 86152 & 28670 & 57482 & 3.00 \\
\hline $\begin{array}{c}\text { Oxyfluorfen@0.24 kg/ha PE + } 1 \text { HW } \\
\text { and } 1 \text { IC at } 40 \text { DAS }\end{array}$ & 1679 & 3950 & 95295 & 29970 & 65325 & 3.18 \\
\hline $\begin{array}{c}\text { Quizalofop-ethyl @ } 40 \text { g/ha POE at } 20 \\
\text { DAS + 1HW and } 1 \text { IC at } 40 \text { DAS }\end{array}$ & 1690 & 3938 & 95732 & 29106 & 66626 & 3.29 \\
\hline $\begin{array}{c}\text { Imazethapyr @ } 75 \text { g/ha POE at } 20 \\
\text { DAS + } 1 \text { HW and } 1 \text { IC at } 40 \text { DAS }\end{array}$ & 1288 & 3076 & 73348 & 28883 & 44465 & 2.54 \\
\hline $\begin{array}{c}\text { Oxadiargyl @ } 90 \text { g/ha POE at } 20 \text { DAS } \\
+1 \text { HW\& } 1 \text { IC at } 40 \text { DAS }\end{array}$ & 1236 & 2908 & 70139 & 28965 & 41174 & 2.42 \\
\hline $\begin{array}{c}\text { Propaquizafop @ } 90 \text { g/ha POE at } 20 \\
\text { DAS + } 1 \text { HW and } 1 \text { IC at } 40 \text { DAS }\end{array}$ & 1581 & 3712 & 89708 & 28830 & 60878 & 3.11 \\
\hline HW and IC at 20 and 40 DAS & 1317 & 3232 & 75431 & 32020 & 43411 & 2.36 \\
\hline $\begin{array}{c}\text { Pendimethalin } 30 \% \text { EC @ } 0.90 \mathrm{~kg} / \mathrm{ha} \\
\text { PE+ Imazethapyr @ } 75 \text { g/ha POE at } 30 \\
\text { DAS }\end{array}$ & 1326 & 3160 & 75460 & 25618 & 49842 & 2.95 \\
\hline $\begin{array}{c}\text { Pendimethalin 30\% EC @ 0.90 kg/ha } \\
\text { PE + Oxadiargyl @ } 90 \text { g/ha POE at } 30 \\
\text { DAS }\end{array}$ & 1262 & 2992 & 71730 & 25700 & 46030 & 2.79 \\
\hline $\begin{array}{l}\text { Weed free (HW and IC at 15,30,45 and } \\
60 \text { DAS) }\end{array}$ & 2115 & 4919 & $\begin{array}{c}11977 \\
7\end{array}$ & 40920 & 78857 & 2.93 \\
\hline Unweeded control & 865 & 1878 & 48322 & 23120 & 25202 & 2.09 \\
\hline S.Em. \pm & 67.3 & 151.8 & & & & \\
\hline C.D.at5\% & 190.8 & 430.5 & & & & \\
\hline C.V.\% & 11.7 & 9.2 & & & & \\
\hline
\end{tabular}

Economics

The maximum net return (78857 Rs./ha) and BCR (2.93) was recorded under weed free treatments. However, the weed management practices involving post-emergence application of Quizal of op-ethyl @ $40 \mathrm{~g} / \mathrm{ha}$ at 20 DAS coupled with one hand weeding and one interculturing at 40 DAS recorded higher net return 66626 Rs./ha over other weed control treatment with 3.29 BCR.(Samant and Mishra 2014 and Bhatt et al., 2010).
Under paucity of labour, farmers are advised to carry out post-emergence application of Quizal of op-ethyl @ 40 g/ha at 20 DAS coupled with one hand weeding and one interculturing at 40 DAS for economical weed control in groundnut.

\section{References}

Agasimani CA, Shanwad UK, Arvindkumar BN and Shivamurthy SD. 2010. 
Integrated weed management-A long term case study in groundnut-wheat cropping system in northern Karnataka. Research Journal of Agricultural Sciences1(3): 196-200.

Bhatt RK, Patel BJ and Bhatt VK. 2010. Evaluation of weed management practices in kharif groundnut under North Gujarat conditions. International Journal of Plant Sciences, 5(2): 442444.

Dutta D, Bandyopadhyay B and Banerjee P. 2005.Integrated weed management in rainfed groundnut (Arachis hypogaea) in acid lateritic soils of West Bengal. Journal of crop and weed 2(1): 47-51.

Kalhapure AH, Shete BT and Bodake PS.2013. Integration of chemical and cultural methods for weed management in groundnut. Indian Journal of Weed Science 45(2): 116119.

Nimju PM 1992. Effect of weed control and nitrogen on weed growth and yield of groundnut. Indian Journal of Agronomy37(3): 484-488.

Patel HF, Patel JC, Maheriya VD and Patel BB. 2013 Integrated weed management in Kharif groundnut (Arachis hypogaea L.). A Quarterly
Journal of Life Sciences10(1b): 320321

Poonia TC, Karwasara PK, Mathukia RK and Sharma A. 2016. Productivity and economics of rainy season groundnut as influenced by weed management practices. Indian Journal of Weed Science 48(4): 400-403.

RamalingamSP, Perumal $\mathrm{M}$ and Chinnagounder C. 2013.Evaluation of new formulation of oxyfluorfen on weed control of groundnut and its residual effect on succeeding crops. Indian Journal of Applied Research 3(6): 16-18.

Samant TK and Mishra KN.2014. Efficacy of post-emergence herbicide quizalofopethyl for controlling grassy weeds in groundnut. Indian Journal of Agricultural Research48(6):488-492.

Solanki RM, Bhalu VB, Jadav KV and kelaiya GR. 2005. Studies on Integrated Weed Management in Irrigated Groundnut. Indian J. Weed Sci. 37 (I \&2): 119120.

Swetha BN, Umesh MR and Agnal MB. 2016. Post- emergence herbicides for weed management in groundnut. Indian Journal of Weed Science 48(3): 294296.

\section{How to cite this article:}

Vora, V.D., A.D. Parmar, D.S. Hirpara, K.K. Kanzaria, N.R. Desai, S.C. Kaneria and Modhavadiya, V.L. 2019. Weed Management in Kharif Groundnut. Int.J.Curr.Microbiol.App.Sci. 8(11): 429-434. doi: https://doi.org/10.20546/ijcmas.2019.811.053 